\title{
Carbon allocation in seedlings of deciduous tree species depends on their shade tolerance
}

\author{
Marian J. Giertych ${ }^{1,2} \cdot$ Piotr Karolewski ${ }^{1} \cdot$ Jacek Oleksyn $^{1}$
}

Received: 30 January 2015/Revised: 19 June 2015/Accepted: 12 September 2015/Published online: 25 September 2015

(C) The Author(s) 2015. This article is published with open access at Springerlink.com

\begin{abstract}
Carbon assimilated during photosynthesis is allocated to basic needs, such as growth, defense, and storage of nutrients. The aim of this study was to explore potential relationships between carbon allocation and light conditions during growth, including shade tolerance of species. We studied species that represent light-demanding (Sorbus aucuparia, Betula pendula), intermediate (Carpinus betulus, Quercus robur), and shade-tolerant (Acer platanoides, Fagus sylvatica) trees. We exposed seedlings to two light treatments (full sunlight and shade), and explored how these conditions affect plant growth and biomass allocation, as well as the levels of phenolic compounds, nonstructural carbohydrates, carbon, and nitrogen. We hypothesized that light-demanding species invest less carbon in chemical defenses against pathogens and/or herbivores compared to shade-tolerant species. On the other hand, light-demanding species showed the greater part of assimilated carbon allocate to growth processes. As a result, the stem diameter above the root collar, the mass of leaves, stems, coarse, and fine roots were larger under full-sunlight conditions in all species, except for greater height of A. platanoides and $Q$. robur under shade conditions. Leaves from full light were characterized by lower nitrogen content, higher carbon and phenolic contents, and a higher carbon/nitrogen ratio compared with leaves from
\end{abstract}

Communicated by U. Feller.

Marian J. Giertych

giertych@man.poznan.pl

1 Polish Academy of Sciences, Institute of Dendrology, Parkowa 5, 62-035 Kórnik, Poland

2 Faculty of Biological Sciences, University of Zielona Góra, 65-516 Zielona Góra, Poland seedlings grown in shade. In the case of shade-tolerant species, a trade-off mechanism can be proposed that such species restrict their usual allocation of carbon to defense and radial growth, while instead of investing it in increasing their heights and storage capacities. According to the light-demanding species, it was not possible to identify a trade-off mechanism and how carbon allocation is restricted upon exposure to shade conditions, except for the reduced allocation to the root mass.

Keywords Biomass allocation - Biometric traits - Lightdemanding trees $\cdot$ Shade-tolerant trees $\cdot$ Growth processes . Defense compounds

\section{Introduction}

Light is one of the most important factors in plant growth and survival and has a direct influence on the level of many metabolites. The availability of light influences the amount of assimilated carbon and affects its allocation (Dudt and Shure 1994; Poorter et al. 2012). Carbon assimilated by tree seedlings during photosynthesis can be allocated to three main processes: growth (including reproduction), defense, and storage. Shade tolerance can determine the relative allocation of carbon among these three processes. It can also be assumed that the patterns of carbon allocation are optimized to maximize survival and growth (Imaji and Seiwa 2010). Compared with light-demanding species, shade-tolerant species allocate more carbon to defense and storage and less to growth. Many researchers have suggested the widespread existence of a trade-off between defense and growth (Zangerl and Bazzaz 1992; Haukioja 2003; Villar et al. 2006), but others have questioned the universality of such observations (Riipi et al. 2002; 
Gaylord et al. 2007). Koricheva (2002), using meta-analysis, described several potential sources of variation in the cost of exhibiting defense mechanisms, such as the presence or absence of herbivores, low or high resource availability, growth rate, and types of defense. She asserted that the failure to detect allocation trade-offs may be a consequence of the particular experimental designs used, and suggested that future studies should examine various aspects of the plant environment: level of competition, herbivore densities, or abiotic conditions.

All plants, including tree and shrub species, can be categorized according to their light requirements. Shade tolerance is usually defined as the capacity to grow in the shade (Niinemets and Valladares 2006), and is measured by the average lowest light levels at which a taxon can survive in a forest understory (Valladares and Niinemets 2008). It is assumed that light-demanding species (which are often early-successional) invest the majority of assimilated carbon in growth (Coley et al. 1985). This growth occurs at the expense of the production of secondary metabolites, which largely consist of compounds active in defense against herbivores and pathogens. Some light-demanding species, losing as many as half of their leaves to herbivory may not impact their capacity for $\mathrm{CO}_{2}$ assimilation because the remaining leaves are better insulated and better supplied with water and nutrients (Heichel and Turner 1983). In the case of trees, this means that the production of wood may not be reduced (Hoogesteger and Karlsson 1992). In contrast to light-demanding species, shade-tolerant species (which are often late-successional) invest a substantial part of their carbon resources in chemical defenses (Coley 1987), such as those provided by phenolic acids, flavonoids, and tannins (Bennett and Wallsgrove 1994). There are strong relationships between the content of phenolic compounds and resistance to insects (Barton and Koricheva 2010). Phenolic compounds are often negatively correlated with nitrogen concentration, and a decrease of phenolics is often observed after nitrogen fertilization (Hakulinen et al. 1995). This is explained by the carbon/nutrient balance hypothesis (Bryant et al. 1983), which states that phenolic compounds, as metabolites containing more carbon, are produced by plants under nutrient-poor conditions, mainly limited by the low level of nitrogen in soil. Under nutrient-rich conditions, carbon is used for the synthesis of proteins and other structural or energy-related compounds. If this hypothesis holds true, we can assume that the sensitivity of plants to herbivores may be connected to the benefits associated with leaves accumulating higher levels of proteins and carbohydrates alongside a lower level of phenolics (Mooney et al. 2009; Wright et al. 2010).

In terms of the association between the carbon/nutrient balance hypothesis and the use of different defense strategies, it is assumed that light-demanding species in contrast to shade-tolerant ones, defend less their leaves (Coley et al. 1985). Indeed, significant differences in the levels of antiherbivore metabolites were observed between birch and alder grazed by the alder beetle, Agelastica alni (Oleksyn et al. 1998). In the leaves of grey alder, the concentration of phenolic compounds was found to increase with increasing perforation of leaves caused by alder beetle. However, in the leaves of birch, this correlation was not observed. In our previous study, we observed that the time required for half of the leaves of a birch subjected to artificial perforation to fall was about 4 weeks earlier than that for control leaves. In the case of alder, this difference was limited to 1 week (Giertych et al. 2006). These observations support the idea that light-demanding and fast-growing species may have less developed leaf defenses.

Against this background, the objective of the present study was to examine the general hypothesis that lightdemanding tree species differ from shade-tolerant ones in terms of their carbon allocation. A more specific hypothesis about differences in defense strategies between fast- and slow-growing species was proposed by Coley (1987) after investigation of tropical plants. This proposes that fastgrowing species are usually light-demanding and do not invest heavily in chemical defense, whereas slow-growing species (which are often shade-tolerant) defend their leaves by producing secondary compounds.

In this study, we specifically ask the following questions: (1) To what extent do light conditions during growth and species' capacity for shade tolerance alter the allocation of mass to different organs? (2) Does the level of carbon allocation to growth, defense, and storage vary depending on species' shade tolerance, and is it affected by the light conditions during growth?

\section{Materials and methods}

\section{Light demands of the species studied}

The species used in this study differ in terms of their light demands (Table 1). We used indicators of shade tolerance (Ellenberg et al. 1991; Zarzycki 1984) and the tolerance scales range constructed by Niinemets and Valladares (2006) to select tree species. We chose two shade-tolerant species (Fagus sylvatica and Acer platanoides), two intermediate ones (Carpinus betulus and Quercus robur), and two light-demanding ones (Sorbus aucuparia and Betula pendula). In order to define an objective measure of shade impact, the ratio of the mean mass of seedlings from shade to the mean mass of seedlings from full light - shade mass effect was calculated (Table 1). 
Table 1 Comparison of ecological light indicators for six examined tree species

\begin{tabular}{lllll}
\hline Species & \multicolumn{4}{l}{ Ecological light indicators } \\
\cline { 2 - 5 } & Ellenberg $^{\mathrm{a}}$ & Niinemets and Valladares $^{\mathrm{b}}$ & Zarzycki $^{\mathrm{c}}$ & Shade mass effect $^{\mathrm{d}}$ \\
\hline Fagus sylvatica & 3 & 4.56 & 3 & 0.542 \\
Acer platanoides & 4 & 4.20 & 4 & 0.349 \\
Carpinus betulus & 4 & 3.97 & 3 & 0.348 \\
Quercus robur & 7 & 2.45 & 4 & 0.186 \\
Betula pendula & 7 & 2.03 & 4 & 0.092 \\
Sorbus aucuparia & 6 & 2.73 & 3 & 0.084 \\
\hline Ellenberg values refer to tree seedlings/saplings in the herbaceous layer & \\
a Ellenberg et al. (1991) & & & \\
b Niinemets and Valladares (2006) \\
c Zarzycki (1984) \\
d Current study (shade mass effect-ratio of means entire-plant mass from shade to mean entire-plant mass \\
from light)
\end{tabular}

\section{Cultivation of seedlings}

One-year-old silver birch (Betula pendula Roth, $N=60$ ), European mountain ash (Sorbus aucuparia L., $N=32$ ), pedunculate oak (Quercus robur L., $N=28$ ), Norway maple (Acer platanoides L., $N=28$ ), common hornbeam (Carpinus betulus L., $N=60$ ), and European beech (Fagus sylvatica $\mathrm{L}$., $N=28$ ) seedlings were grown individually in $2000-\mathrm{cm}^{3}$ pots filled with a $1: 1(\mathrm{v} / \mathrm{v})$ mixture of forest soil and peat. Seedlings were obtained from commercial nursery (birch and hornbeam) or cultured from seeds in fullsunlight conditions. Before the experiments, seedlings were replanted to the pots and fertilized $\left(2 \mathrm{~kg} / 1000 \mathrm{dm}^{3}\right)$ with granulate Osmocote slow-release (5-6 months) fertilizer containing: $15 \% \mathrm{~N}\left(7 \% \mathrm{NO}_{3}^{-}\right.$and $\left.8 \% \mathrm{NH}_{4}{ }^{+}\right), 9 \% \mathrm{P}$ $\left(\mathrm{P}_{2} \mathrm{O}_{5}\right), 12 \% \mathrm{~K}\left(\mathrm{~K}_{2} \mathrm{O}\right)$, and $2.5 \% \mathrm{Mg}(\mathrm{MgO})$. At the beginning of the growing season (in April), the height and diameter of each seedling were measured (the initial height was later used as a covariant during the statistical analyses of growth parameters), and the seedlings of each species were randomly divided into two groups. The first group was placed into two identical shade houses covered with black polypropylene shade cloth, which allowed the transmittance of $5 \%$ light (shade treatment). The second group of seedlings was grown in two plots with full exposure to sunlight. The sites where all treatments and blocks were carried out were no more than $10 \mathrm{~m}$ apart. Temperature and relative humidity during the experiments were monitored using HOBO data loggers (HOBO H08032-08, Onset Computers, USA). Based the monthly average values, it was found that shade decreased temperature of about $2{ }^{\circ} \mathrm{C}$ but increased the relative humidity of dozen percent. This work was carried out at the experimental field of the Institute of Dendrology in Kórnik, Poland $\left(52^{\circ} 14^{\prime} \mathrm{N} ; 17^{\circ} 05^{\prime} \mathrm{E} ; 75 \mathrm{~m}\right.$ altitude). During growing season, the seedlings were watered as necessary and all weeds were periodically removed.

\section{Growth parameters, morphological, and chemical analyses}

For each seedling, the height and diameter above the root collar were measured at the beginning of the experiment, and three times during the growing season. In October, toward the end of the growing season, eight seedlings of each species from the two light treatments were randomly chosen for morphological and chemical analyses. In a few cases, owing to a small amount of available material, some analyses were carried out with fewer replications. The roots were rinsed, and each seedling was divided into four parts: coarse roots (diameter $>2 \mathrm{~mm}$ ), fine roots (diameter $<2 \mathrm{~mm}$ ), stem (with branches), and leaves. Subsamples of leaves and fine roots from each seedling were used to determine projected leaf area (PLA) using WinFolia Pro, and total surface root area (TRA) and fine root length using both WinRhizo softwares (Regent Instruments, Inc., Quebec, Canada). Specific leaf area (SLA: defined as the PLA divided by the leaf dry mass, $\mathrm{cm}^{2} \mathrm{~g}^{-1}$ ) and the total root area and length for each seedling were calculated. All parts of the seedlings were oven-dried $\left(65^{\circ} \mathrm{C}\right.$ for $48 \mathrm{~h}$ ), ground to a fine powder using a Mikro-Feinmühle Culatti mill (IKA Labortechnik, Staufen, Germany), and stored in plastic boxes. Descriptions and abbreviations of all measured parameters are given in Table 2.

Nitrogen $(\mathrm{N})$ and carbon (C) concentrations in the leaves were measured using the Elemental Combustion System CHNS-O (Costech Analytical Technologies Inc., Valentia, USA). The concentration of phenolic compounds (TPh) was measured colorimetrically using Folin and Ciocalteu's Phenol Reagent (Sigma F-9252), following 
Table 2 Parameters of plant morphology and chemistry, with their abbreviations and units of measurement

\begin{tabular}{|c|c|c|}
\hline Parameter & Symbol or abbreviation & Units or definition \\
\hline Projected leaf area & PLA & $\mathrm{cm}^{2}$ \\
\hline Specific leaf area & SLA & $\mathrm{cm}^{2} \mathrm{~g}^{-1}$ \\
\hline Total surface root area & TRA & $\mathrm{cm}^{2}$ \\
\hline Leaf mass ratio & LMF & $\mathrm{g}$ leaf $\mathrm{g}^{-1}$ plant \\
\hline Stem mass ratio & SMF & $\mathrm{g}$ stem $\mathrm{g}^{-1}$ plant \\
\hline Root mass ratio & RMF & $\mathrm{g}$ root $\mathrm{g}^{-1}$ plant \\
\hline Leaf area ratio & LAR & $\mathrm{cm}^{2}$ leaves $\mathrm{g}^{-1}$ plant \\
\hline Leaf carbon ratio & LCR & $\mathrm{g}$ leaf carbon $\mathrm{g}^{-1}$ plant carbon \\
\hline Stem carbon ratio & SCR & $\mathrm{g}$ stem carbon $\mathrm{g}^{-1}$ plant carbon \\
\hline Root carbon ratio & $\mathrm{RCR}$ & $\mathrm{g}$ root carbon $\mathrm{g}^{-1}$ plant carbon \\
\hline Stem height increment & & $\begin{array}{l}\mathrm{cm} \text {; difference between final seedling height and } \\
\text { initial seedling height }\end{array}$ \\
\hline Stem radial increment & & $\begin{array}{l}\mathrm{mm} \text {; difference between final seedling diameter } \\
\text { above root collar and initial seedling diameter } \\
\text { above root collar }\end{array}$ \\
\hline Shade mass effect & & $\begin{array}{l}\text { Ratio of means entire-plant mass from shade to } \\
\text { mean entire-plant mass from light }\end{array}$ \\
\hline Carbon & $\mathrm{C}$ & $\%$ of dry mass $(\mathrm{DM})$ \\
\hline Nitrogen & $\mathrm{N}$ & $\%$ of DM \\
\hline Soluble carbohydrates & $\mathrm{SC}$ & $\mathrm{mg} \mathrm{g}^{-1} \mathrm{DM}$ \\
\hline Starch & & $\mathrm{mg} \mathrm{g}^{-1} \mathrm{DM}$ \\
\hline Total soluble phenolics & $\mathrm{TPh}$ & $\mu \mathrm{mol}$ chlorogenic acid $\mathrm{g}^{-1} \mathrm{DM}$ \\
\hline
\end{tabular}

Johnson and Schaal (1957), as modified by Singleton and Rossi (1965). The content of total phenols was expressed as $\mu$ mol chlorogenic acid per gram of dry mass. Total soluble carbohydrate and starch concentrations were determined by a modified version of the methods described by Hansen and Møller (1975) and Haissig and Dickson (1979). Carbohydrates were extracted from tissue powder in methanol-chloroform-water (12:5:3,v:v:v), and the tissue residue was used to determine the starch content. Concentrations of soluble carbohydrates and starch (with glucose as a standard) are expressed as \% of glucose per gram of dry mass.

It is clear that seedling mass depends on the amount of accumulated carbon. Accordingly, in order to clarify the distribution of carbon allocation, we expressed some of our results as the ratios of growth parameters or chemical compositions to seedling masses.

\section{Statistical analyses}

After initial testing of residuals normality (Shapiro-Wilk test) and equal variance (Levene test), analysis of covariance (ANCOVA) was used to evaluate the influence of species, light treatment, and their interaction on growth and morphological parameters. The initial height was used as a covariant (except for the final diameter, for which the initial diameter was used). Analysis of variance (ANOVA) was used to assess the influence of species, light treatment, and their interaction on allocation ratios, leaf morphology parameters, contents of leaf $\mathrm{TPh}$, carbohydrate, $\mathrm{N}$, and $\mathrm{C}$. The results expressed in percent were arcsin-transformed for normality for ANOVA analyses. Relations between the shade tolerance (shade mass effect) and growth, morphological, and chemical parameters were expressed as a linear regression. Shade mass effect was used as independent variable in the regression analysis. All analyses were performed using JMP software (version 7.0.2; SAS Institute, Cary, NC, USA).

\section{Results}

\section{Influence of light conditions and shade tolerance on growth parameters}

The variability of reactions in examined species was high, and almost all tested morphological and chemical parameters demonstrated a significant statistical difference (Tables 3, 4, 5). The shade-tolerant species were characterized by smaller differences in entire-plant mass between shade and light treatment (higher values of shade mass effect). Regardless of light condition, the shade mass effect correlated negatively with aboveground to belowground mass ratio (Fig. 1). Light-demanding species allocate more 
Table 3 Summary of ANCOVA for seedling height, seedling diameter, seedling dry mass, stem dry mass, leaf dry mass, root dry mass, coarse root dry mass, fine root dry mass, fine root length, and surface root area with light conditions of growth, species, and interactions

\begin{tabular}{|c|c|c|c|c|c|c|c|c|c|c|c|c|c|}
\hline \multirow[t]{2}{*}{ Treatment } & \multicolumn{4}{|c|}{ Seedling height } & \multicolumn{3}{|c|}{ Seedling diameter ${ }^{*}$} & \multicolumn{3}{|c|}{ Seedling mass } & \multicolumn{3}{|c|}{ Stem mass } \\
\hline & $D f$ & Error $d f$ & $F$ & $P$ & Error $d f$ & $F$ & $P$ & Error $d f$ & $F$ & $P$ & Error $d f$ & $F$ & $P$ \\
\hline Species (S) & 5 & 212 & 105.89 & $<0.0001$ & 218 & 43.13 & $<0.0001$ & 75 & 27.60 & $<0.0001$ & 76 & 18.96 & $<0.0001$ \\
\hline Light (L) & 1 & 212 & 94.80 & $<0.0001$ & 218 & 835.14 & $<0.0001$ & 75 & 419.70 & $<0.0001$ & 76 & 207.28 & $<0.0001$ \\
\hline $\mathrm{S} \times \mathrm{L}$ & 5 & 212 & 27.60 & $<0.0001$ & 218 & 33.71 & $<0.0001$ & 75 & 22.56 & $<0.0001$ & 76 & 16.38 & $<0.0001$ \\
\hline $\begin{array}{l}\text { Initial height } \\
\text { (covariate) }^{*}\end{array}$ & 1 & 212 & 93.64 & $<0.0001$ & 218 & 137.67 & $<0.0001$ & 75 & 29.20 & $<0.0001$ & 76 & 43.00 & $<0.0001$ \\
\hline \multirow[t]{2}{*}{ Treatment } & \multicolumn{4}{|c|}{ Leaf mass } & \multicolumn{3}{|c|}{ Root mass } & \multicolumn{3}{|c|}{ Coarse root mass } & \multicolumn{3}{|c|}{ Fine root mass } \\
\hline & $D f$ & Error $d f$ & $F$ & $P$ & Error $d f$ & $F$ & $P$ & Error $d f$ & $F$ & $P$ & Error $d f$ & $F$ & $P$ \\
\hline Species (S) & 1 & 75 & 40.47 & $<0.0001$ & 76 & 21.41 & $<0.0001$ & 75 & 34.88 & $<0.0001$ & 75 & 6.79 & $<0.0001$ \\
\hline Light (L) & 2 & 75 & 94.52 & $<0.0001$ & 76 & 369.49 & $<0.0001$ & 75 & 230.63 & $<0.0001$ & 75 & 270.21 & $<0.0001$ \\
\hline $\mathrm{S} \times \mathrm{L}$ & 3 & 75 & 30.99 & $<0.0001$ & 76 & 9.24 & $<0.0001$ & 75 & 9.21 & $<0.0001$ & 75 & 7.48 & $<0.0001$ \\
\hline $\begin{array}{r}\text { Initial height } \\
\text { (covariate) }\end{array}$ & 1 & 75 & 2.09 & 0.1520 & 76 & 13.33 & 0.0005 & 75 & 12.59 & 0.0007 & 75 & 7.89 & 0.0063 \\
\hline \multirow[t]{2}{*}{ Treatment } & \multirow[t]{2}{*}{$D f$} & \multicolumn{4}{|c|}{ Fine root length } & \multicolumn{4}{|c|}{ Surface root area } & & & & \\
\hline & & Error $a$ & $F$ & & $P$ & Error $d f$ & $F$ & $P$ & & & & & \\
\hline Species (S) & 1 & 75 & & 2.03 & 0.0837 & 75 & 3.3 & & 085 & & & & \\
\hline Light (L) & 2 & 75 & & 3.58 & $<0.0001$ & 75 & 156.0 & $<0.0$ & 001 & & & & \\
\hline S x L & 3 & 75 & & 3.21 & 0.0112 & 75 & 4.0 & & 026 & & & & \\
\hline $\begin{array}{r}\text { Initial height } \\
\text { (covariate) }\end{array}$ & 1 & 75 & & 0.06 & 0.8029 & 75 & 0.2 & & 008 & & & & \\
\hline
\end{tabular}

Initial seedling height was used as a covariate $(*$ for diameter, initial diameter was used as a covariate) to adjust initial size differences between seedlings. Values in boldface indicate $P<0.05$

biomass to aboveground parts of seedlings, and shade conditions even enhance the relationship.

Exposure to shaded conditions clearly reduced the growth of all species (Tables 3,6). The extent of the reduction was correlated with the shade tolerance of the species, and was greater in light-demanding species. This became the basis for calculating shade mass effect. The light conditions clearly influenced seedling height, diameter, and mass. Among all of the growth-related traits, only plant height of the shade-tolerant species in shade conditions was similar or greater than that of the same species growing under full sunlight. Other growth-related traits (diameters above the root collars, and masses of leaves, stems, total roots, coarse roots, and fine roots) in all species showed greater values under full-sunlight conditions than under shade conditions (the exception is the greater mass of $F$. sylvatica leaves under shade). There were significant interactions between light conditions and tree species for all these traits (Table 3). It means that the shade conditions resulted reduction of the growth-related traits, particularly in the light-demanding species (Table 6; see Tukey test results). The reduction of mass associated with shade conditions was organ-specific, and was the greatest for roots and the smallest for leaves. The light conditions influenced mass allocation to stem (SMF), roots (RMF), and leaves (LMF), with shade-tolerant species allocating mass predominantly roots. Interactions between light conditions and tree species in terms of biomass allocation to different organs in seedlings were not statistically significant (Table 4).

The light conditions and tree species affected almost all leaf parameters in all species. The seedlings grown in the shade were characterized by lower leaf mass (except $F$. sylvatica) and greater SLA and mean PLA values than those of plants grown in full sunlight (Tables 6, 7). There were also significant interactions between tree species and light conditions for SLA (Table 4). The largest increase of SLA and the largest decrease of leaf mass under shade conditions were exhibited by the light-demanding species (Table 7; see Tukey test results). The light-demanding species scored the largest leaf area ratio (LAR) under light conditions (23,7 and 79,3 for $S$. aucuparia and B. pendula, respectively) and the largest increase of LAR under shade conditions (221.7 and 216.5 for $S$. aucuparia and $B$. 
Table 4 Summary of ANOVA for allocation to stem (SMF), allocation to leaves (LMF), allocation to roots (RMF), specific leaf area (SLA), mean leaf mass, mean leaf area, stem carbon, stem nitrogen, and stem $\mathrm{C} / \mathrm{N}$ ratio with light conditions of growth, species, and interactions

\begin{tabular}{|c|c|c|c|c|c|c|c|c|c|c|}
\hline \multirow[t]{2}{*}{ Treatment } & \multicolumn{4}{|c|}{ SMF } & \multicolumn{3}{|l|}{ LMF } & \multicolumn{3}{|l|}{ RMF } \\
\hline & $D f$ & Error $d f$ & $F$ & $P$ & Error $d f$ & $F$ & $P$ & Error $d f$ & $F$ & $P$ \\
\hline Species (S) & 5 & 76 & 20.59 & $<0.0001$ & 76 & 20.03 & $<0.0001$ & 76 & 115.37 & $<0.0001$ \\
\hline Light (L) & 1 & 76 & 12.93 & 0.0006 & 76 & 2.56 & 0.1136 & 76 & 64.72 & $<0.0001$ \\
\hline $\mathrm{S} \times \mathrm{L}$ & 5 & 76 & 0.38 & 0.8630 & 76 & 0.71 & 0.6152 & 76 & 1.99 & 0.0894 \\
\hline \multirow[t]{2}{*}{ Treatment } & \multicolumn{4}{|c|}{ SLA } & \multicolumn{3}{|c|}{ Mean leaf mass } & \multicolumn{3}{|c|}{ Mean leaf area } \\
\hline & $D f$ & Error $d f$ & $F$ & $P$ & Error $d f$ & $F$ & $P$ & Error $d f$ & $F$ & $P$ \\
\hline Species (S) & 5 & 70 & 15.17 & $<0.0001$ & 70 & 11.36 & $<0.0001$ & 70 & 16.66 & $<0.0001$ \\
\hline Light (L) & 1 & 70 & 514.83 & $<0.0001$ & 70 & 35.67 & $<0.0001$ & 70 & 5.83 & 0.0184 \\
\hline $\mathrm{S} \times \mathrm{L}$ & 5 & 70 & 10.48 & $<0.0001$ & 70 & 6.78 & $<0.0001$ & 70 & 4.98 & 0.0006 \\
\hline \multirow[t]{2}{*}{ Treatment } & \multicolumn{4}{|c|}{ Stem carbon } & \multicolumn{3}{|c|}{ Stem nitrogen } & \multicolumn{3}{|c|}{ Stem $\mathrm{C} / \mathrm{N}$ ratio } \\
\hline & $D f$ & Error $d f$ & $F$ & $P$ & Error $d f$ & $F$ & $P$ & Error $d f$ & $F$ & $P$ \\
\hline Species (S) & 5 & 77 & 56.63 & $<0.0001$ & 77 & 6.84 & $<0.0001$ & 77 & 8.31 & $<0.0001$ \\
\hline Light (L) & 1 & 77 & 6.72 & 0.0114 & 77 & 233.07 & $<0.0001$ & 77 & 174.11 & $<0.0001$ \\
\hline $\mathrm{S} \times \mathrm{L}$ & 5 & 77 & 2.70 & 0.0266 & 77 & 6.50 & $<0.0001$ & 77 & 8.71 & $<0.0001$ \\
\hline
\end{tabular}

Values in boldface indicate $P<0.05$

Table 5 Summary of ANOVA for leaf soluble carbohydrates, leaf starch, root soluble carbohydrates root starch, leaf carbon, leaf nitrogen, leaf $\mathrm{C} / \mathrm{N}$ ratio, leaf $\mathrm{TPh}$, root carbon, root nitrogen, and root $\mathrm{C} / \mathrm{N}$ ratio with species, light conditions of growth and interactions

\begin{tabular}{|c|c|c|c|c|c|c|c|c|c|c|c|c|c|}
\hline \multirow[t]{2}{*}{ Treatment } & \multicolumn{4}{|c|}{ Leaf soluble carbohydrates } & \multicolumn{3}{|c|}{ Leaf starch } & \multicolumn{3}{|c|}{ Root soluble carbohydrates } & \multicolumn{3}{|c|}{ Root starch } \\
\hline & $D f$ & Error $d f$ & $F$ & $P$ & Error $d f$ & $F$ & $P$ & Error $d f$ & $F$ & $P$ & Error $d f$ & $F$ & $P$ \\
\hline Species (S) & 5 & 65 & 9.77 & $<0.0001$ & 65 & 6.60 & $<0.0001$ & 75 & 3.17 & 0.0119 & 75 & 6.06 & $<0.0001$ \\
\hline Light (L) & 1 & 65 & 22.75 & $<0.0001$ & 65 & 7.39 & 0.0084 & 75 & 30.20 & $<0.0001$ & 75 & 18.12 & $<0.0001$ \\
\hline $\mathrm{S} \times \mathrm{L}$ & 5 & 65 & 8.37 & $<0.0001$ & 65 & 6.52 & $<0.0001$ & 75 & 1.48 & 0.2067 & 75 & 2.35 & 0.0486 \\
\hline \multirow[t]{2}{*}{ Treatment } & \multicolumn{4}{|c|}{ Leaf carbon } & \multicolumn{3}{|c|}{ Leaf nitrogen } & \multicolumn{3}{|c|}{ Leaf $\mathrm{C} / \mathrm{N}$ ratio } & \multicolumn{3}{|l|}{ Leaf TPh } \\
\hline & $D f$ & Error $d f$ & $F$ & $P$ & Error $d f$ & $F$ & $P$ & Error $d f$ & $F$ & $P$ & Error $d f$ & $F$ & $P$ \\
\hline Species (S) & 5 & 67 & 9.69 & $<0.0001$ & 67 & 11.20 & $<0.0001$ & 67 & 6.10 & 0.0001 & 67 & 41.04 & $<0.0001$ \\
\hline Light (L) & 1 & 67 & 141.69 & $<0.0001$ & 67 & 432.53 & $<0.0001$ & 67 & 210.23 & $<0.0001$ & 67 & 464.05 & $<0.0001$ \\
\hline $\mathrm{S} \times \mathrm{L}$ & 5 & 67 & 4.17 & 0.0023 & 67 & 4.42 & 0.0016 & 67 & 4.36 & 0.0017 & 67 & 8.98 & $<0.0001$ \\
\hline \multirow[t]{2}{*}{ Treatment } & \multicolumn{4}{|c|}{ Root carbon } & \multicolumn{4}{|c|}{ Root nitrogen } & \multicolumn{3}{|c|}{ Root $\mathrm{C} / \mathrm{N}$ ratio } & & \\
\hline & $D f$ & Error $d f$ & $F$ & $P$ & Error & $d f$ & $F$ & $P$ & Error $d f$ & $F$ & $P$ & & \\
\hline $\begin{array}{c}\text { Species } \\
\text { (S) }\end{array}$ & 5 & 76 & 16.25 & $<0.0001$ & 76 & & 6.81 & $<0.0001$ & 76 & 7.54 & $<0.0001$ & & \\
\hline Light (L) & 1 & 76 & 4.38 & 0.0396 & 76 & & 267.99 & $<0.0001$ & 76 & 190.80 & $<0.0001$ & & \\
\hline $\mathrm{S} \times \mathrm{L}$ & 5 & 76 & 5.12 & 0.0004 & 476 & & 5.75 & 0.0001 & 76 & 7.13 & $<0.0001$ & & \\
\hline
\end{tabular}

Values in boldface indicate $P<0.05$ 


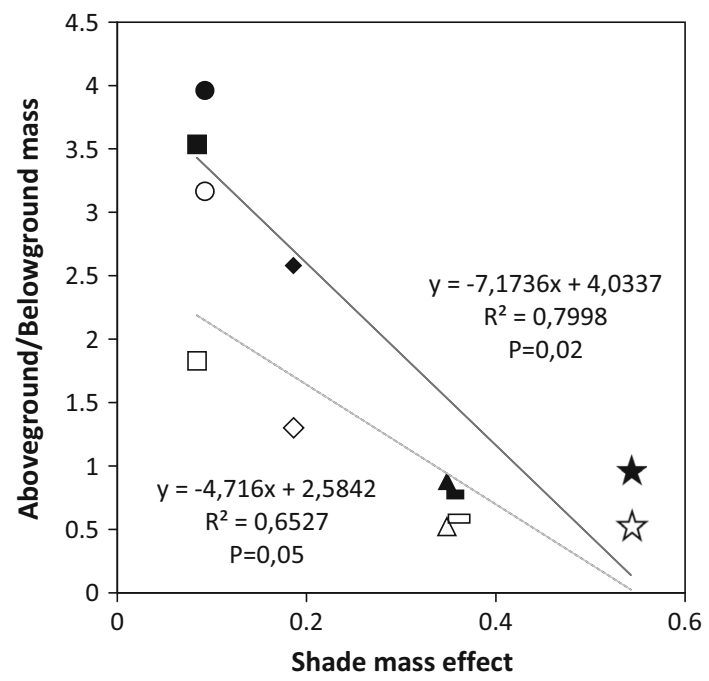

Fig. 1 Relationship between shade mass effect and aboveground to underground mass ratio for six species: asterisks Fagus sylvatica; box Acer platanoides; triangle Quercus robur; diamond Carpinus betulus; circle Betula pendula; square Sorbus aucuparia growing under shade (filled symbol) and full-sunlight (open symbol) conditions

pendula, respectively). The relationship between shade mass effect and LAR was significant only in the case of shade condition (Fig. 2). Shade causes a high significant decrease in all measured root parameters such as total root mass, coarse root mass, fine root mass, and surface area (Tables 3, 6).

\section{Influence of light conditions and shade tolerance on chemical composition}

The light conditions and tree species significantly influenced all the investigated chemical elements and compounds in leaves, stems, and roots. The leaves of species subjected to full-sunlight conditions had less nitrogen and more carbon, phenolic compounds and a higher carbon/ nitrogen $(\mathrm{C} / \mathrm{N})$ ratio. In most cases, it was also a significant interaction between light conditions and species. The reason is that the observed differences between the contents of the examined compounds and elements were greater in the light-demanding species (Tables 5, 8).

The efficiency of carbon assimilation, when expressed as a ratio of carbon in the entire plant to leaf mass, showed significant dependence from shade tolerance (Fig. 3). This relationship is very similar for both light conditions. The highest efficiency of carbon assimilation showed a shadetolerant species ( $F$. sylvatica and A. platanoides) and the lowest light-demanding (B. pendula and $S$. aucuparia).

For stems, the contents of carbon and nitrogen, as well as the $\mathrm{C} / \mathrm{N}$ ratio, depended on light conditions and on species (Table 4). The light conditions also altered the root contents of the examined chemical elements and compounds (Tables $5,7,8$ ). The results were similar to those in leaves; however, the content of soluble carbohydrates was lower and that of starch was higher in roots compared with those in leaves.

The relationships between stem height increment and diameter increment to seedling mass, all of which may reflect how carbon is invested by a plant, were found to depend on the light conditions and the species' tolerance of shade (Fig. 4). Under full-sunlight conditions, these relationships were similar for all groups of examined species. However, under shade conditions, the increases in the ratio height increment to seedling mass were the highest in the two light-demanding species (Fig. 4). Although the correlation coefficient was not significant, a clear trend is well noticed. The ratio of stem diameter increment to seedling mass for the shade-tolerant species was lower under shade conditions compared to the full sunlight. The relationships of carbohydrate concentrations in roots or leaves and total phenolic concentration in leaves to seedling mass also depended on species' shade tolerance (shade mass effect) and light conditions during growth (Fig. 5). For full-sunlight conditions, these relationships were significant, lightdemanding species under full sunlight invested less carbon to phenolic compounds and carbohydrates. Shade conditions increased the ratios of carbohydrate and phenolic contents to seedling mass in light-demanding species. For shade-tolerant species, shade conditions increased the ratios of carbohydrate to seedling mass, but decreased the ratio phenolic content to seedling mass (Fig. 5).

\section{Discussion}

For the seedlings of forest trees, during their first few years of life, development very often occurs in deep shade and shade tolerance plays a key role in the seedlings survival (Walters and Reich 1999). Our results showed that shade tolerance influences carbon allocation. The higher ratios of stem height increment and stem radial increment to seedling mass in light-demanding species (Fig. 4) indicate that these species invest proportionally more of their carbon into growth compared with shade-tolerant species. Higher allocation of carbon to growth processes in the case of light-demanding species was particularly pronounced under shade conditions. Niinemets (1998) maintains that, under conditions of low irradiance, shade-tolerant Acer platanoides and the intermediate species Quercus robur allocate more resources for promoting an increase in height. In our experiment, the mean heights (Table 6) of both of these species were also greater in the shade than under the full-sunlight conditions. This is connected with the so-called "lammas shoots," which were observed in 
Table 6 Mean (SD) of biometric parameters depending on species and light conditions

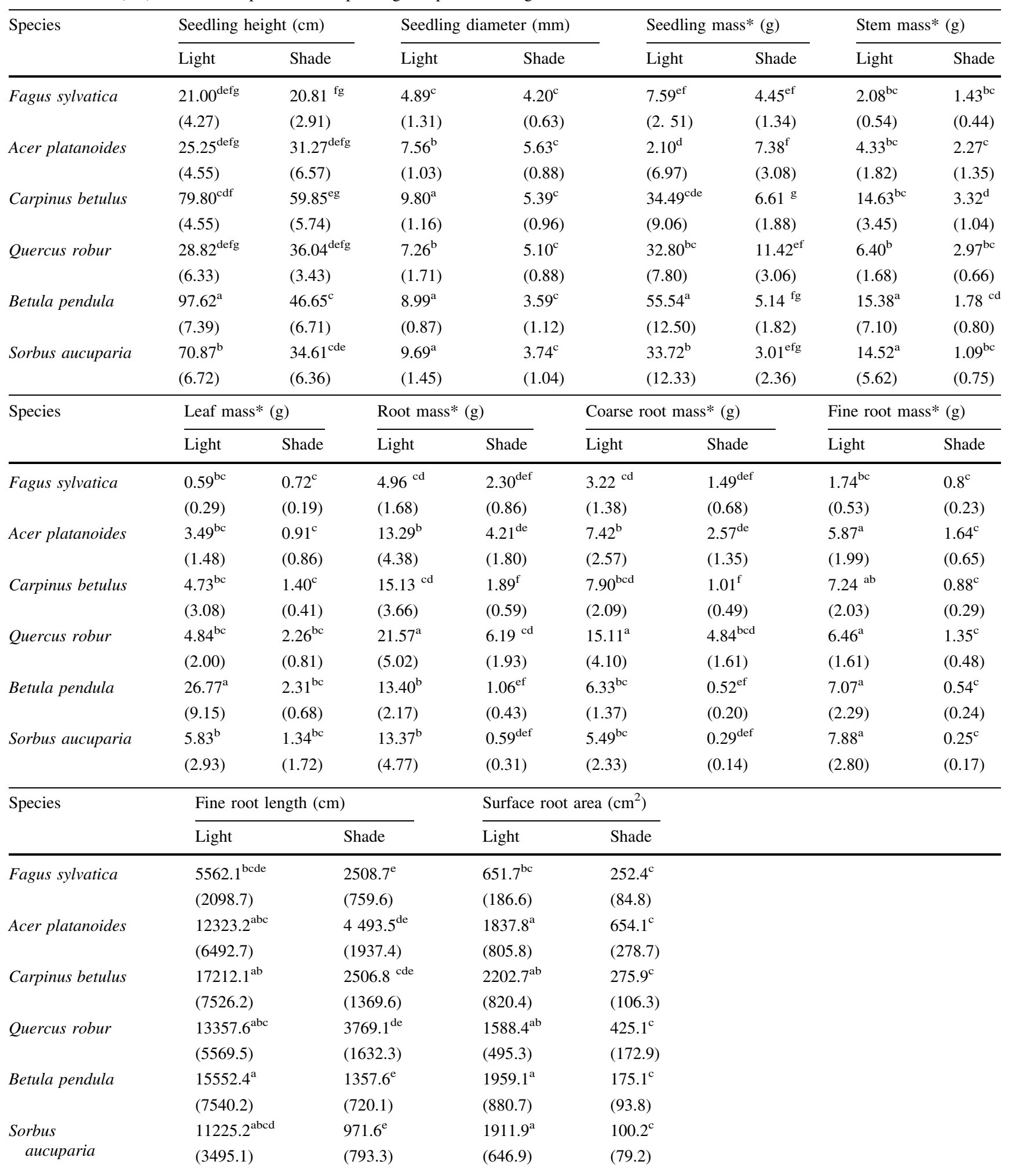

Means with the same letter are not significantly different $(P<0.05$, ANCOVA followed by Tukey HSD test)

* dry mass 
Table 7 Mean (SD) of allocation, leaf parameters, and stem chemical compositions depending on species and light conditions

\begin{tabular}{|c|c|c|c|c|c|c|}
\hline \multirow[t]{2}{*}{ Species } & \multicolumn{2}{|c|}{ SMF ( $g$ shoot $\mathrm{g}^{-1}$ plant) } & \multicolumn{2}{|c|}{ LMF (g leaf $g^{-1}$ plant) } & \multicolumn{2}{|c|}{ RMF (g root $\mathrm{g}^{-1}$ plant) } \\
\hline & Light & Shade & Light & Shade & Light & Shade \\
\hline \multirow[t]{2}{*}{ Fagus sylvatica } & $0.28^{\mathrm{cd}}$ & $0.32^{\mathrm{bcd}}$ & $0.08^{\mathrm{b}}$ & $0.16^{\mathrm{b}}$ & $0.65^{\mathrm{ab}}$ & $0.51^{\mathrm{cd}}$ \\
\hline & $(0.06)$ & $(0.05)$ & $(0.03)$ & $(0.01)$ & $(0.05)$ & $(0.06)$ \\
\hline \multirow[t]{2}{*}{ Acer platanoides } & $0.20^{\mathrm{d}}$ & $0.29^{\mathrm{cd}}$ & $0.16^{\mathrm{b}}$ & $0.13^{\mathrm{b}}$ & $0.63^{\mathrm{ab}}$ & $0.57^{\mathrm{abc}}$ \\
\hline & $(0.04)$ & $(0.07)$ & $(0.05)$ & $(0.11)$ & $(0.05)$ & $(0.07)$ \\
\hline \multirow[t]{2}{*}{ Carpinus betulus } & $0.43^{\mathrm{abc}}$ & $0.50^{\mathrm{a}}$ & $0.13^{\mathrm{b}}$ & $0.21^{\mathrm{b}}$ & $0.44^{\mathrm{cd}}$ & $0.28^{\mathrm{fg}}$ \\
\hline & $(0.05)$ & $(0.04)$ & $(0.06)$ & $(0.03)$ & $(0.05)$ & $(0.04)$ \\
\hline \multirow[t]{2}{*}{ Quercus robur } & $0.20^{\mathrm{d}}$ & $0.27^{\mathrm{cd}}$ & $0.15^{\mathrm{b}}$ & $0.19^{\mathrm{b}}$ & $0.66^{\mathrm{a}}$ & $0.54^{\text {bcd }}$ \\
\hline & $(0.03)$ & $(0.04)$ & $(0.04)$ & $(0.06)$ & $(0.04)$ & $(0.05)$ \\
\hline \multirow[t]{2}{*}{ Betula pendula } & $0.28^{\mathrm{cd}}$ & $0.34^{\mathrm{bcd}}$ & $0.47^{\mathrm{a}}$ & $0.46^{\mathrm{a}}$ & $0.25^{\mathrm{g}}$ & $0.20^{\mathrm{g}}$ \\
\hline & $(0.12)$ & $(0.05)$ & $(0.12)$ & $(0.06)$ & $(0.04)$ & $(0.02)$ \\
\hline \multirow[t]{2}{*}{ Sorbus aucuparia } & $0.42^{\mathrm{ab}}$ & $0.48^{\mathrm{ab}}$ & $0.17^{\mathrm{b}}$ & $0.24^{\mathrm{b}}$ & $0.40^{\mathrm{ef}}$ & $0.27^{\mathrm{fg}}$ \\
\hline & $(0.06)$ & $(0.21)$ & $(0.07)$ & $(0.31)$ & $(0.07)$ & $(0.13)$ \\
\hline \multirow[t]{2}{*}{ Species } & \multicolumn{2}{|c|}{ SLA $\left(\mathrm{cm}^{2} \mathrm{~g}^{-1}\right)$} & \multicolumn{2}{|c|}{ Mass of one leaf $(\mathrm{g})$} & \multicolumn{2}{|c|}{ Area of one leaf $\left(\mathrm{cm}^{2}\right)$} \\
\hline & Light & Shade & Light & Shade & Light & Shade \\
\hline \multirow[t]{2}{*}{ Fagus sylvatica } & $153.26^{\mathrm{c}}$ & $282.18^{\mathrm{b}}$ & $0.04^{\mathrm{d}}$ & $0.04^{\mathrm{d}}$ & $6.00^{\mathrm{d}}$ & $11.30^{\mathrm{d}}$ \\
\hline & $(17.49)$ & (19.16) & $(0.01)$ & $(0.01)$ & $(1.72)$ & $(2.64)$ \\
\hline \multirow[t]{2}{*}{ Acer platanoides } & $170.36^{\mathrm{c}}$ & $402.36^{\mathrm{a}}$ & $0.23^{\mathrm{ab}}$ & $0.10^{\mathrm{cd}}$ & $39.18^{\mathrm{a}}$ & $37.86^{\mathrm{ab}}$ \\
\hline & $(24.61)$ & $(67.62)$ & $(0.09)$ & $(0.07)$ & $(15.09)$ & (19.66) \\
\hline \multirow[t]{2}{*}{ Carpinus betulus } & $159.94^{\mathrm{c}}$ & $318.90^{\mathrm{b}}$ & $0.08^{\mathrm{cd}}$ & $0.05^{\mathrm{d}}$ & $12.07^{\mathrm{d}}$ & $16.73^{\mathrm{cd}}$ \\
\hline & $(33.70)$ & $(37.85)$ & $(0.03)$ & $(0.03)$ & $(2.25)$ & $(8.02)$ \\
\hline \multirow[t]{2}{*}{ Quercus robur } & $122.71^{\mathrm{c}}$ & $286.22^{\mathrm{b}}$ & $0.15^{\mathrm{bc}}$ & $0.12^{\mathrm{cd}}$ & $18.09^{\mathrm{abc}}$ & $32.38^{\mathrm{cd}}$ \\
\hline & $(19.22)$ & $(35.63)$ & $(0.05)$ & $(0.04)$ & $(3.50)$ & $(9.59)$ \\
\hline \multirow[t]{2}{*}{ Betula pendula } & $166.29^{c}$ & $468.20^{\mathrm{a}}$ & $0.10^{\mathrm{cd}}$ & $0.08^{\mathrm{cd}}$ & $16.58^{\mathrm{cd}}$ & $37.23^{\mathrm{ab}}$ \\
\hline & $(19.08)$ & $(65.83)$ & $(0.04)$ & $(0.01)$ & $(5.63)$ & $(5.05)$ \\
\hline \multirow[t]{2}{*}{ Sorbus aucuparia } & $124.24^{\mathrm{c}}$ & $393.46^{\mathrm{a}}$ & $0.22^{\mathrm{a}}$ & $0.06^{\mathrm{cd}}$ & $25.95^{\mathrm{abc}}$ & $23.77^{\mathrm{bcd}}$ \\
\hline & $(32.19)$ & $(84.44)$ & $(0.12)$ & $(0.03)$ & $(12.26)$ & $(6.55)$ \\
\hline \multirow[t]{2}{*}{ Species } & \multicolumn{2}{|c|}{ Stem carbon $(\% \mathrm{DM})$} & \multicolumn{2}{|c|}{ Stem nitrogen (\%DM) } & \multicolumn{2}{|c|}{ Stem $\mathrm{C} / \mathrm{N}$ ratio } \\
\hline & Light & Shade & Light & Shade & Light & Shade \\
\hline \multirow[t]{2}{*}{ Fagus sylvatica } & $46.69^{\mathrm{cd}}$ & $46.78^{c}$ & $0.87^{\text {cdef }}$ & $1.18^{\mathrm{abc}}$ & $54.51^{\mathrm{cd}}$ & $39.95^{\mathrm{d}}$ \\
\hline & $(1.17)$ & $(0.55)$ & $(0.11)$ & $(0.08)$ & $(6.52)$ & $(2.74)$ \\
\hline Acer platanoides & $47.09^{c}$ & $46.24^{\mathrm{cd}}$ & $0.87^{\text {cde }}$ & $1.41^{\mathrm{a}}$ & $56.37^{\mathrm{cd}}$ & $34.36^{\mathrm{d}}$ \\
\hline & $(0.38)$ & $(0.53)$ & $(0.16)$ & $(0.30)$ & $(13.17)$ & $(8.06)$ \\
\hline Carpinus betulus & $44.47^{\mathrm{e}}$ & $44.66^{\mathrm{de}}$ & $0.57^{\mathrm{efg}}$ & $1.33^{\mathrm{ab}}$ & $82.85^{\mathrm{b}}$ & $33.98^{\mathrm{d}}$ \\
\hline & $(0.37)$ & $(0.30)$ & $(0.13)$ & $(0.16)$ & $(26.78)$ & $(4.29)$ \\
\hline Quercus robur & $44.97^{\mathrm{de}}$ & $44.79^{\mathrm{de}}$ & $0.55^{\mathrm{fg}}$ & $0.95^{\mathrm{bcd}}$ & $83.61^{\mathrm{b}}$ & $50.41^{\mathrm{d}}$ \\
\hline & $(0.90)$ & $(2.12)$ & $(0.08)$ & $(0.25)$ & $(12.00)$ & $(16.45)$ \\
\hline Betula pendula & $50.27^{\mathrm{a}}$ & $49.01^{\mathrm{ab}}$ & $0.64^{\text {defg }}$ & $1.47^{\mathrm{a}}$ & $80.16^{\mathrm{bc}}$ & $34.31^{\mathrm{d}}$ \\
\hline & $(0.93)$ & $(0.23)$ & $(0.08)$ & $(0.26)$ & (11.09) & $(6.51)$ \\
\hline Sorbus aucuparia & $47.56^{\mathrm{bc}}$ & $45.90^{\text {cde }}$ & $0.49^{g}$ & $1.50^{\mathrm{a}}$ & $99.46^{\mathrm{a}}$ & $33.23^{\mathrm{d}}$ \\
\hline & $(1.12)$ & (1.67) & $(0.08)$ & $(0.47)$ & $(14.88)$ & (10.64) \\
\hline
\end{tabular}

Means with the same letter are not significantly different $(P<0.05$, ANOVA followed by Tukey HSD test) 


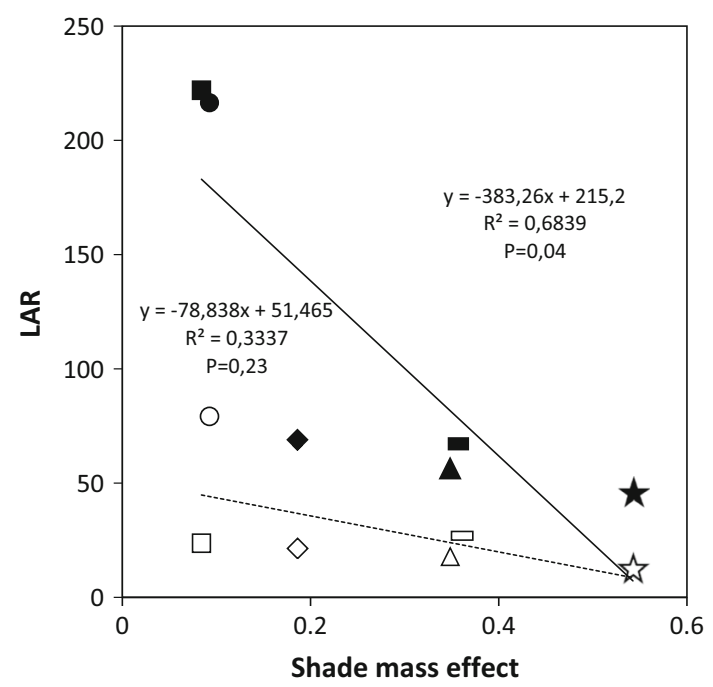

Fig. 2 Relationship between shade mass effect and leaf area ratio $\left(\mathrm{cm}^{2}\right.$ leaves $\mathrm{g}^{-1}$ plant) for six species: asterisks Fagus sylvatica; box Acer platanoides; triangle Quercus robur; diamond Carpinus betulus; circle Betula pendula; square Sorbus aucuparia growing under shade (filled symbol) and full-sunlight (open symbol) conditions

some seedlings growing under shade conditions and increased mean height relative to that of seedlings grown under high light intensities. Moreover, the pattern of carbon allocated to increase height in shade-tolerant and intermediate species was less dependent on light conditions than that in light-demanding species.

Rapid shoot elongation is an adaptation of light-demanding species to achieve high growth quickly when intense light conditions appear (Imaji and Seiwa 2010). In natural forests, conditions of intense light are found under gaps in the canopy, which are usually short-lived in mature forests (Madsen and Hahn 2008). Therefore, the seedlings of light-demanding species only have a few years to reach the forest canopy; otherwise, at strata nearer the ground, they are outcompeted by slower growing shade-tolerant species. Light-demanding species were previously shown to allocate more mass to the stem and less to the roots (Paz 2003), which was similar to the results in our experiment. Shade conditions increased the allocation to aboveground part of plant and decreased that of root (RMF), regardless of the shade tolerance of the species. However, this increase is higher in light-demanding species. Despite the increase of the LMF in the majority of examined species, the seedlings growing in the shade had a greater mean leaf area (Table 7) and greater LAR (Fig. 2). McCarthy and Enquist (2007) suggest that intraspecific variability in biomass allocation is correlated with environmental factors. An increase in leaf area is connected with the need to increase light capture. These results support the optimal partitioning theory (Thornley 1972; Bloom et al. 1985), which suggests that plants allocate biomass to components that will most facilitate the acquisition of those resources that are in limited supply at the time.

The influence of light conditions during growth on the chemical composition of plants was as expected. Under shade conditions, the carbon content in leaves, stem, and roots was lower, regardless of the shade tolerance of species. Walters and Reich (1999) suggested that young seedlings of shade-tolerant species do not have advantages over light-demanding species in terms of the efficiency of capture of carbon under low-light conditions. However, in our experiment, shade-tolerant species assimilated more carbon per leaf mass unit than intermediate or light-demanding species (Fig. 3). This confirms the suggestions of Teskey and Shrestha (1985) that shade-tolerant species may have more efficient systems for assimilating carbon dioxide.

The nitrogen content in leaves, stem, and roots of seedlings grown in the shade was approximately double than under full-sunlight conditions. A higher content of nitrogen in leaves upon growth in the shade was also reported by Niinemets (1997) and Baraza et al. (2004). However, the influence of shading on the concentration of nitrogen in roots and stem in our experiment differs from the findings from some other studies. Machado and Reich (2006) showed a significant decrease of nitrogen in the stem with increasing shade, but only for one (Pinus strobus) of three examined cold-temperate tree species. VillarSalvador et al. (2004), who investigated the effect of nitrogen fertilization and shading on the functional quality of Quercus ilex seedlings, also found a significantly lower nitrogen contents in root and stem in plants grown under shade conditions than in those grown under full sunlight. These differences can be explained by the greater size of a plant upon growth in full-sunlight conditions, such that the available nitrogen is diluted across the greater mass of the plant.

According to the hypothesis of Coley (1987), shadetolerant species allocate more carbon to metabolites involved in defense against pathogens and herbivores. In our experiment, the level of phenolic compounds in shadetolerant species was also higher than that in light-demanding species, regardless of growth conditions. Shadetolerant plants also have a longer leaf lifespan (Hallik et al. 2009); therefore, they are forced to establish defense systems for their leaves, especially in the case of plants growing in shaded conditions, which are usually more attractive to herbivores (Henriksson et al. 2003;). Other studies showed that shade-tolerant tree species have higher levels of defense metabolites than light-demanding species (Dudt and Shure 1994; Imaji and Seiwa 2010). We also noted the important interaction in phenolic content between light conditions during growth and shade tolerance. In this 
Table 8 Mean (SD) of leaf and root chemical compositions depending on species and light conditions

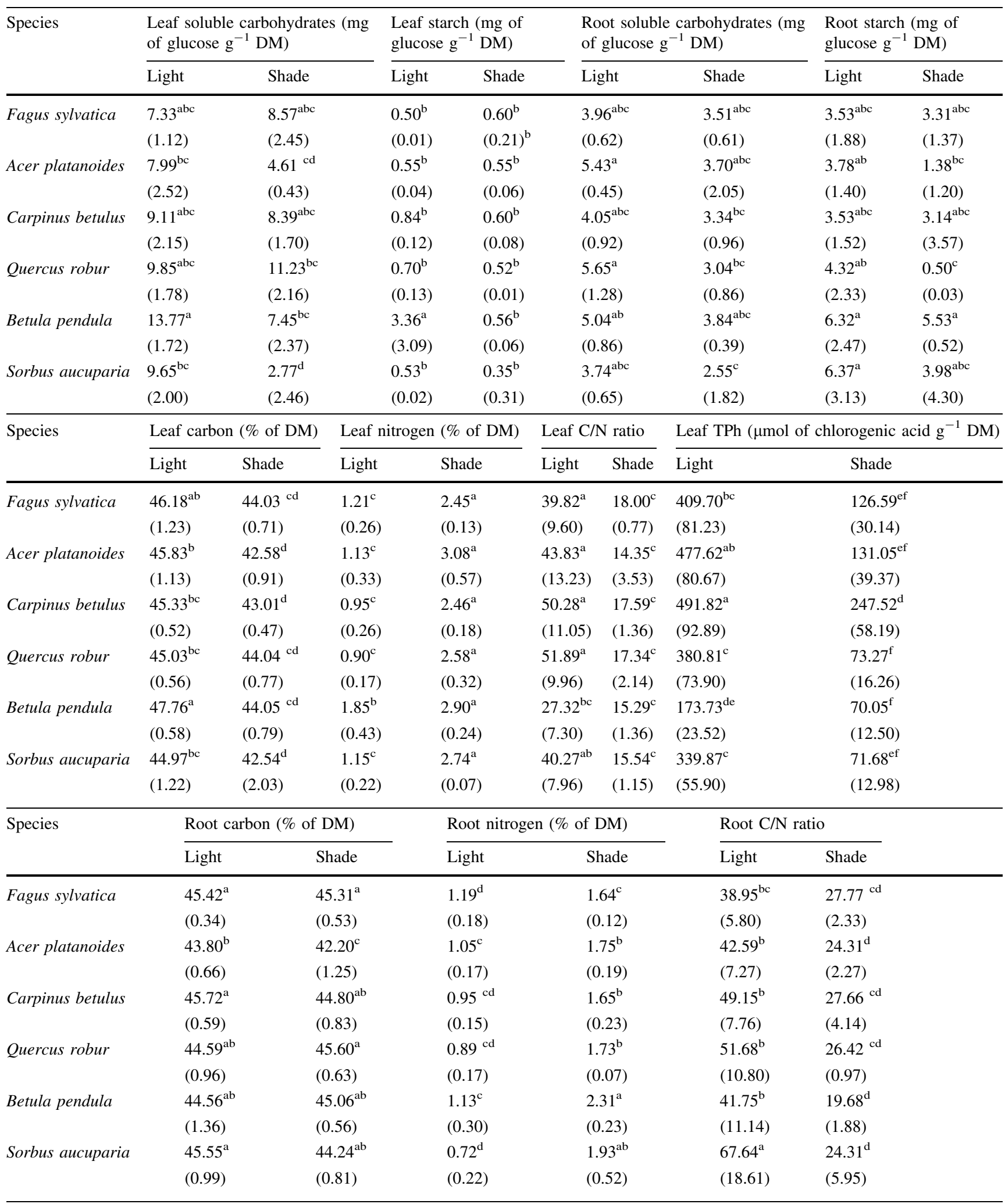

Means with the same letter are not significantly different $(P<0.05$, ANOVA followed by Tukey HSD test) 


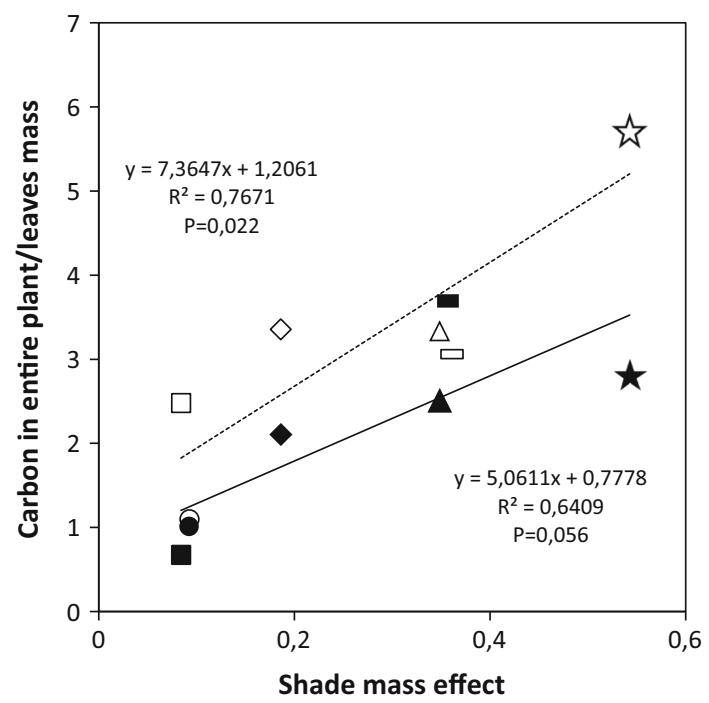

Fig. 3 Relationship between shade mass effect and the ratio carbon content in the entire plant to leaf mass for six species: asterisks Fagus sylvatica; box Acer platanoides; ttriangle Quercus robur; diamond Carpinus betulus; circle Betula pendula; square Sorbus aucuparia growing under shade (filled symbol) and full-sunlight (open symbol) conditions

study, the decrease of leaf phenolic compounds under lowlight conditions was greater in light-demanding species than in shade-tolerant ones. However, the amount of carbon allocated to phenolic compounds (phenolic compound content/seedling mass) in light-demanding species was significantly higher under shade conditions. In shade-tolerant species, the amount of carbon invested in defense metabolites (phenolics) was greater under full-sunlight conditions. This can be explained by the role of phenolics in protection against photodamage (Close and McArthur 2002). Despite the fact that the efficiency of carbon assimilation, expressed as the ratio of carbon in the entire plant to the leaf mass in shade-tolerant species, depends from shade mass effect (Fig. 3), shade-tolerant species contained more phenolic compounds and they allocated more carbon to defense than light-demanding or intermediate species (Fig. 5).

Our results suggest that the level of carbon allocation to carbohydrates differs between the various plant organs and light conditions. Higher ratios of leaf soluble carbohydrates/seedling mass and root soluble carbohydrates/seedling mass under shade conditions may reflect the lack of a trade-off relationship between storage and growth or storage and defense. According to Kobe (1997), allocation of carbon to stored carbohydrate may be an effective strategy in shade tolerance; however, many other researchers dispute the hypothesis (Machado and Reich 2006; Piper et al. 2009). A higher level of allocation of carbon in the form of carbohydrates to roots by shade-tolerant species under full-
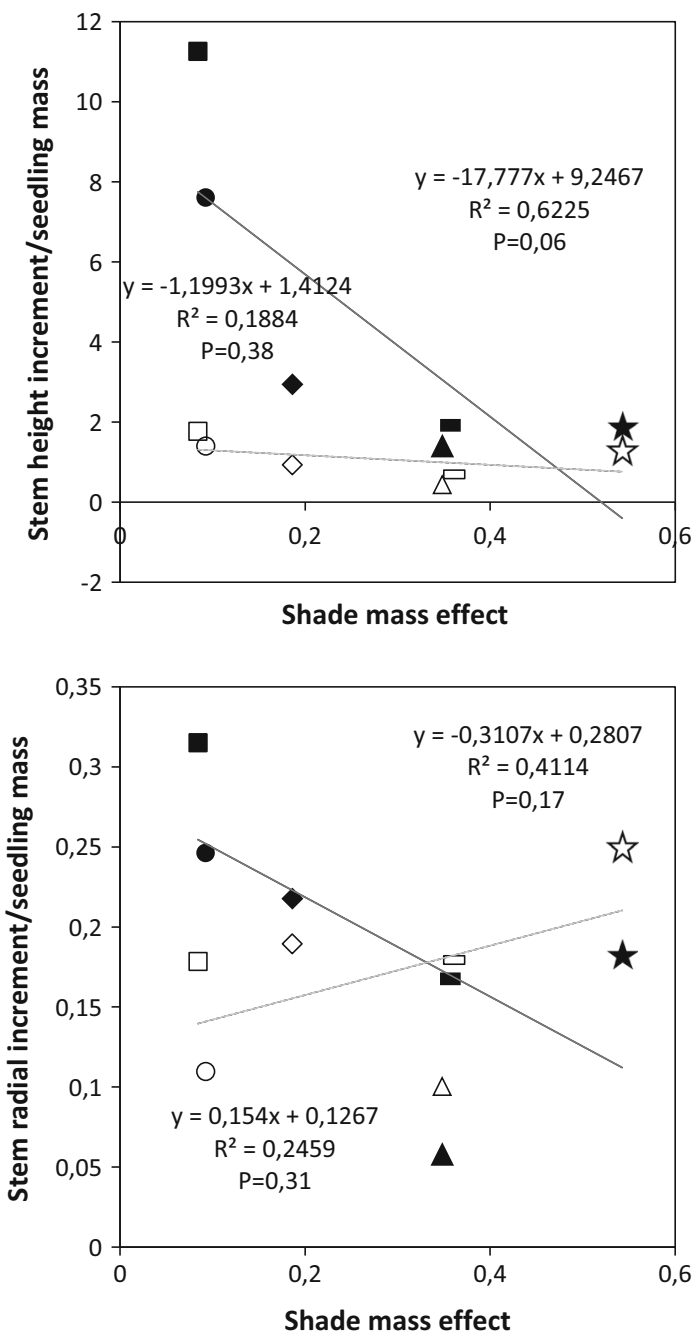

Fig. 4 Relationship between shade mass effect and the ratio stem height increment to seedlings mass and stem radial increment to seedlings mass for six species: asterisks Fagus sylvatica; box Acer platanoides; ttriangle Quercus robur; diamond Carpinus betulus; circle Betula pendula; square Sorbus aucuparia growing under shade (filled symbol) and full-sunlight (open symbol) conditions

sunlight conditions and to leaves by light-demanding species under shade conditions (Table 8) may be characteristic only for the end of the growing season, that is, when the studies were carried out. There is thus a need to investigate these effects during the whole growing season.

In conclusion, this study demonstrated that the shade tolerance of tree seedlings influences carbon allocation. When expressed as the ratio of carbon in the entire plant to leaf mass, the efficiency of carbon assimilation correlated positively with shade mass effect (Fig. 3). In the case of shade-tolerant species, the findings suggest the existence of a trade-off mechanism. Under shade conditions, the shadetolerant species restrict the allocation of carbon to roots, defense mechanisms (such as the accumulation of 

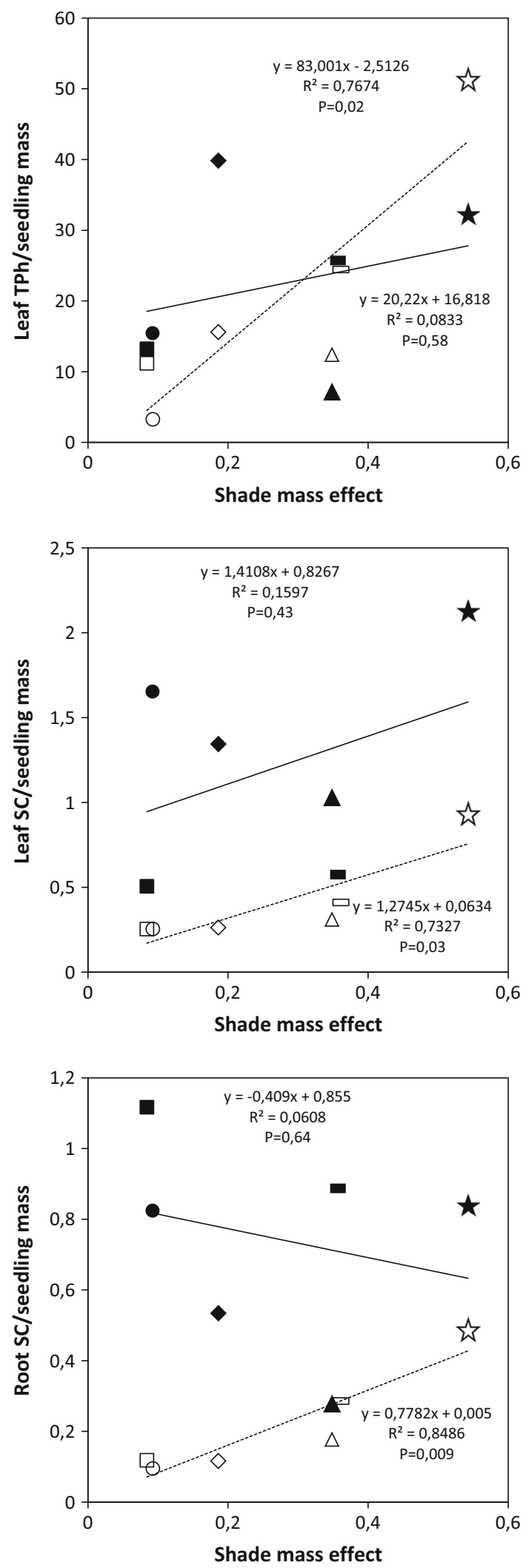

4Fig. 5 Relationship between shade mass effect and leaf soluble phenolics (TPh), leaf soluble carbohydrates (SC), root soluble carbohydrates (SC) to seedlings mass for six species: asterisks Fagus sylvatica; box Acer platanoides; triangle Quercus robur; diamond Carpinus betulus; circle Betula pendula; square Sorbus aucuparia growing under shade (filled symbol) and full-sunlight (open symbol) conditions

phenolics), and radial growth. Carbon assimilated by shade-tolerant seedlings of deciduous trees under shade conditions is instead allocated much more to the accumulation of storage compounds (nonstructural carbohydrates) and the promotion of plant height. In contrast, in lightdemanding seedlings of deciduous trees grown under shade conditions, carbon is allocated not only to structural tissues, enabling a high level of growth, but also to nonstructural carbohydrates in leaves or roots. However, in the case of these light-demanding species, we did not note a trade-off mechanism. Under stress conditions (shade), the ratios of examined growth parameters and metabolites to seedling mass were always higher than under full-sunlight conditions. Only the allocation to roots was lower.

Author contribution statement MJG, PK, and JO conceived and designed the experiments. MJG cultured plant materials, collected samples, performed the experiments and the data analysis, and drafted the earlier versions of the manuscript. PK and JO revised the manuscript.

Acknowledgments We thank Alicja Bukowska, Ewa Mąderek, Anna Nowak, and Łucja Mądra for their help with the chemical analysis. We kindly thank "Genedit" for linguistic support. This study was partly supported by the Ministry of Sciences and Higher Education, Poland (Grant no. 2PO4F 06427).

Open Access This article is distributed under the terms of the Creative Commons Attribution 4.0 International License (http://crea tivecommons.org/licenses/by/4.0/), which permits unrestricted use, distribution, and reproduction in any medium, provided you give appropriate credit to the original author(s) and the source, provide a link to the Creative Commons license, and indicate if changes were made.

\section{References}

Baraza E, Gomez J, Hodar J, Zamora R (2004) Herbivory has a greater impact in shade than in sun: response of Quercus pyrenaica seedlings to multifactorial environmental variation. Can J Bot 82:357-364

Barton KE, Koricheva J (2010) The ontogeny of plant defense and herbivory: characterizing general patterns using meta-analysis. Am Nat 175:481-493 
Bennett RN, Wallsgrove RM (1994) Secondary metabolites in plant defence mechanisms. New Phytol 127:617-633

Bloom AJ, Chapin FS, Mooney HA (1985) Resource limitation in plants-an economic analogy. Annu Rev Ecol Syst 16:363-392

Bryant JP, Chapin FS, Klein DR (1983) Carbon/nutrient balance of boreal plants in relation to vertebrate herbivore. Oikos 40:357-368

Close DC, McArthur C (2002) Rethinking the role of many plant phenolics-protection from photodamage not herbivores? Oikos 99:166-172

Coley PD (1987) Interspecific variation in plant anti-herbivore properties: the role of habitat quality and rate of distribution. New Phytol 106:251-263

Coley PD, Bryant JP, Chapin FS (1985) Resource availability and plant antiherbivore defense. Science 230:895-899

Dudt JF, Shure DJ (1994) The influence of light and nutrients on foliar phenolics and insect herbivory. Ecology 75:86-98

Ellenberg H, Weber HE, Düll R, Wirth V, Werner W, Paulissen D (1991) Zeigerwerte von Pflanzen in Mitteleuropa. Scr Geobot $18: 1-248$

Gaylord ML, Kolb TE, Wallin KF, Wagner MR (2007) Seasonal dynamics of tree growth, physiology, and resin defenses in a northern Arizona ponderosa pine forest. Can J For Res 37:1173-1183

Giertych MJ, Karolewski P, Zytkowiak R, Oleksyn J (2006) Differences in defence strategies against herbivores between two pioneer tree species: Alnus glutinosa (L.) Gaertn. and Betula pendula Roth. Pol J Ecol 54:181-187

Haissig BE, Dickson RE (1979) Starch measurement in plant tissue using enzymatic hydrolysis. Physiol Plant 47:151-157

Hakulinen J, Julkunen-Tiitto R, Tahvanainen J (1995) Dose nitrogen fertilization have an impact on the trade-off between willow growth and defensive secondary metabolism? Trees Struct Funct 9:235-240

Hallik L, Niinemets U, Wright IJ (2009) Are species shade and drought tolerance reflected in leaf-level structural and functional differentiation in Northern Hemisphere temperate woody flora? New Phytol 184:257-274

Hansen J, Møller I (1975) Percolation of starch and soluble carbohydrates from plant tissue for quantitative determination with anthrone. Anal Biochem 68:87-94

Haukioja E (2003) Putting the insect into the birch-insect interaction. Oecologia 136:161-168

Heichel GH, Turner NC (1983) $\mathrm{CO}_{2}$ assimilation of primary and regrowth foliage of red maple (Acer rubrum L.) and red oak (Quercus rubra L.): response to defoliation. Oecologia 57:14-19

Henriksson J, Haukioja E, Ossipov V, Ossipova S, Sillanpaa S, Kapari L, Pihlaja K (2003) Effects of host shading on consumption and growth of the geometrid Epirrita autumnata: interactive roles of water, primary and secondary compounds. Oikos 103:3-16

Hoogesteger J, Karlsson PS (1992) Effects of defoliation on radial stem growth and photosynthesis in the mountain birch (Betula pubescens ssp. tortuosa). Funct Ecol 6:317-323

Imaji A, Seiwa K (2010) Carbon allocation to defense, storage, and growth in seedlings of two temperate broad-leaved tree species. Oecologia 162:273-281

Johnson G, Schaal LA (1957) Accumulation of phenolic substances and ascorbic acids in potato tuber tissue upon injury and their possible role in disease and resistance. Am Potato J 34:200-202

Kobe RK (1997) Carbohydrate allocation to storage as a basis of interspecific variation in sapling survivorship. Oikos 80:226-233

Koricheva J (2002) Meta-analysis of sources of variation in fitness costs of plant antiherbivore defenses. Ecology 83:176-190

Machado JL, Reich PB (2006) Dark respiration rate increases with plant size in saplings of three temperate tree species despite decreasing tissue nitrogen and nonstructural carbohydrates. Tree Physiol 26:915-923

Madsen P, Hahn K (2008) Natural regeneration in a beech-dominated forest managed by close-to-nature principles —a gap cutting based experiment. Can J For Res 38:1716-1729

McCarthy MC, Enquist BJ (2007) Consistency between an allometric approach and optimal partitioning theory in global patterns of plant biomass allocation. Funct Ecol 21:713-720

Mooney EH, Tiedeken EJ, Muth NZ, Niesenbaum RA (2009) Differential induced response to generalist and specialist herbivores by Lindera benzoin (Lauraceae) in sun and shade. Oikos 118:1181-1189

Niinemets $\ddot{U}$ (1997) Role of foliar nitrogen in light harvesting and shade tolerance of four temperate deciduous woody species. Funct Ecol 11:518-531

Niinemets Ü (1998) Growth of young trees of Acer platanoides and Quercus robur along a gap-understory continuum: interrelationships between allometry, biomass partitioning, nitrogen, and shade tolerance. Int J Plant Sci 159:318-330

Niinemets Ü, Valladares F (2006) Tolerance to shade, drought, and waterlogging of temperate Northern Hemisphere trees and shrubs. Ecol Monogr 76:521-547

Oleksyn J, Karolewski P, Giertych MJ, Żytkowiak R, Reich PB, Tjoelker MG (1998) Primary and secondary host plants differ in photosynthetic response to herbivory: evidence from Alnus and Betula grazed by the alder beetle, Agelastica alni. New Phytol 140:239-249

Paz H (2003) Root/shoot allocation and root architecture in seedlings: variation among forest sites, microhabitats, and ecological groups. Biotropica 35:318-332

Piper FI, Reyes-Diaz M, Corcuera LJ, Lusk CH (2009) Carbohydrate storage, survival, and growth of two evergreen Nothofagus species in two contrasting light environments. Ecol Res 24:1233-1241

Poorter H, Niklas KJ, Reich PB, Oleksyn J, Poot P, Mommer L (2012) Biomass allocation to leaves, stems and roots: meta-analyses of interspecific variation and environmental control. New Phytol 193:30-50

Riipi M, Ossipov V, Lempa K, Haukioja E, Koricheva J, Ossipova S, Pihlaja K (2002) Seasonal changes in birch leaf chemistry: are there trade-offs between leaf growth, and accumulation of phenolics? Oecologia 130:380-390

Singleton VI, Rossi JA (1965) Colorimetry of total phenolics with phosphomolybdic-phosphotungstic acid reagent. Am J Enol Vitic 16:144-158

Teskey RO, Shrestha RB (1985) A relationship between carbon dioxide photosynthetic efficiency and shade tolerance. Physiol Plant 63:126-132

Thornley JH (1972) A balanced quantitative model for root: shoot ratios in vegetative plants. Ann Bot 36:431-441

Valladares F, Niinemets U (2008) Shade tolerance, a key plant feature of complex nature and consequences. Annu Rev Ecol Syst 39:237-257

Villar R, Robleto JR, De Jong Y, Poorter H (2006) Differences in construction costs and chemical composition between deciduous and evergreen woody species are small as compared to differences among families. Plant Cell Environ 29:1629-1643

Villar-Salvador P, Planelles R, Enríquez E, Rubira JP (2004) Nursery cultivation regimes, plant functional attributes, and field performance relationships in the Mediterranean oak Quercus ilex L. For Ecol Manage 196:257-266

Walters MB, Reich PB (1999) Low-light carbon balance and shade tolerance in the seedlings of woody plants: do winter deciduous and broad-leaved evergreen species differ? New Phytol 143:143-154 
Wright DM, Jordan GJ, Lee WG, Duncan RP, Forsyth DM, Coomes DA (2010) Do leaves of plants on phosphorus-impoverished soils contain high concentrations of phenolic defence compounds? Funct Ecol 24:52-61

Zangerl AR, Bazzaz FA (1992) Theory and pattern in plant defense allocation. In: Fritz RS, Simms EL (eds) Plant resistance to herbivores and pathogens. The University of Chicago Press, Chicago, pp 363-391

Zarzycki K (1984) Indicator values of vascular plants in Poland. Polish Academy of Sciences, Institute of Botany, Kraków 